\title{
Reception of Individual Stylistic Manners the Lyrics of K.D. Balmont
}

\section{Bezrukov Andrey Nikolaevich ${ }^{1}$}

Associate professor of Bashkir State University, Branch in Birsk, Birsk, Russia.

(date of receiving: December, 2017; date of acceptance: March, 2018)

\begin{abstract}
Identifying the features of the individual author's style is one of the most difficult procedures for the linguistic evaluation of the author's text. In article presents the analysis of the language of lyric poetry by Konstantin Balmont from the position of receptive aesthetics, principles of structuralism, and hermeneutic theory. This research concerns the peculiarities of rhythmic and melodies of poetic texts by K.D. Balmont, which fixate the author's individual manner of artistic thinking. Analysis of the poems showed that K.D. Balmont nomination of poetic language uses as an effective form of realization of semantic potential. Consequently, the contact between the author and the reader are carried out both within the universal language system and is corrected by the contextual reception of the text. Also in the work it was determined that the poetic dominants of the individual author's style K.D. Balmont, his diversity and richness to a greater extent receives an effective fixation at the level of phonetics, melodies, rhythmic and sound organization.
\end{abstract}

Keywords: Konstantin Balmont, Reception of the Text, Poetic Style, Poetic Language, Melody, Rhythm, Semantic of the Text, Literary Discourse.

1. E-mail: in_text@mail.ru 


\title{
Рецепция индивидуально-стилевой манеры лирики К.Д. Бальмонта
}

\section{Безруков Андрей Николаевич ${ }^{1}$}

Доцент Башкирского государственного университета, Бирский филиал, Бирск, Россия.

(дата получения: декабрь 2017 г.; дата принятия: март 2018 г.)

\begin{abstract}
Аннотация
Выявление особенностей индивидуально-авторского стиля является одной из самых сложных процедур при лингвистической оценке авторского текста. В статье осуществлен анализ языка лирики Константина Бальмонта с позиций рецептивной эстетики, принципов структурализма, а также герменевтической теории. Данное исследование касается особенностей ритмики и мелодики поэтических текстов К.Д. Бальмонта, акцентно фиксирующих индивидуально-авторскую манеру художественного мышления. Анализ стихотворений показал, что К.Д. Бальмонт номинацию поэтического языка использует как действенную форму реализации смыслового потенциала. Следовательно, контакт автора и читателя осуществляется как в пределах универсальной языковой системы, так и корректируется контекстуально-ситуативной рецепцией текста. Также в работе было определено, что поэтические доминанты индивидуально-авторского стиля К.Д. Бальмонта, его разнообразие и богатство в большей степени получает действенную фиксацию на уровне фонетики, мелодики, ритмики и звукописи.
\end{abstract}

Ключевые слова: Константин Бальмонт, Рецепция Текста, Поэтический Стиль, Поэтический Язык, Мелодика, Ритмика, Смысловая Нагрузка Текста, Художественный Дискурс.

1. E-mail: in_text@mail.ru 


\section{Введение}

Художественное наследие Константина Бальмонта - представителя серебряного века, поэта начала XX столетия в русской литературы - явление необычайно знаковое и интересное. Нарочито возникающие эстетические противоречия, возникающие в лирике К.Д. Бальмонта, манифестированы автором амбивалентным синтезом формального уровня и содержательного слоя, музыкальной парадигмы и смысловой дисперсии. Наличный бальмонтовский текст вбирает в себя нечто большее, чем только сам язык как таковой, звук, смысл, эстетический потенциал. Он как бы открывает перед потенциальным читателем безграничные пределы языковой знаковой системы, некие универсалии вербального, того, что характерно и свойственно мировой литературе в целом, естественному языку в частности.

Следует заметить, что рецепция и анализ языка, индивидуально-авторского стиля К.Д. Бальмонта привлекает большинство исследователей (Молчанова 2002; Петрова 2012; Петрова 2015; Суханова 2016) в первую очередь тем, что каждая новая отмеченная или найденная универсальная поэтическая, либо языковая примета его лирических текстов в свою очередь высвечивает спектр множества неповторимых черт. Сколько бы читатель не возвращался к восприятию бальмонтовского конструкта - новый, смысловой, семантический, коннотативный реверс в итоге неизбежен. В данной работе осуществлена попытка анализа языка лирики К.Д. Бальмонта с позиций лингвосемантики, стихосложения, семиотики, в работе также дана оценка специфики художественного мышления К.Д. Бальмонта как одного из представителей эпохи «серебряного века», периода влияющего на дальнейший ход развития мирового литературного процесса.

Основными методами (Эйхенбаум 1922; Лотман 1972; Жирмунский 2004; Винокур 2006; Тюпа 2009; Безруков 2015) исследования являются: структурный, сравнительно-сопоставительный, типологический, а также метод 
целостной концептуальной, рецептивной оценки. Материалы работы, на наш взгляд, могут быть интересны и перспективно полезны в ходе дальнейшего изучения поэтического языка и стиля Константина Бальмонта, также они могут быть точечно применены в русле определения магистральных художественных примет и черт миропонимания поэта, конкретизации ведущих принципов поэтики миромоделирования символизма.

Правильной, на наш взгляд, является мысль, что интерпретация - это стержень науки о литературе (Д.С. Лихачев). Любая интерпретация художественного текста (Хализев 2002. 323-327; Тюпа 2008. 102-128) строится на внутренних особенностях дешифровки некоей эстетической гармонии. Лирический текст явление многогранное и сложное в сопоставлении с прозой или драматургией. Исследователь лирики заинтересован как в определении общих черт данной формы, так и выявлении индивидуально-авторских особенностей в соответствии с тем или иным автором. Именно лирика требует от художника слова максимальной проработки языка, определения собственно для себя набора активного/частотного словаря, действенных/акцентных приемов воссоздания персонифицированного образа лирического героя, а также целостного образа мира.

\section{Основная часть}

В теории литературы уже достаточно давно устоялось, что лирика - есть самый выразительный род литературы, выстроенный на человеческих эмоциях, переживаниях, чувствах, внутренних импульсах, особых эстетических впечатлениях. Этим, вероятно, лирика и сложна, порой непонятна или противоречива в трактовке. Фридрих Шлегель заметил, что: «лирика всегда изображает лишь само по себе определенное состояние, например, порыв удивления, вспышку гнева, боли, радости и т.д., - некое 
целое, собственно не являющееся целым. Здесь необходимо единство чувства» (Шлегель 1983. 62). Манифестация чувств, эмоций в поэтическом тексте происходит не буквальным называнием того или иного переживания/чувства, но звуковым, фонетическим, лексическим, синтаксическим, либо графическим (принцип параграфемики) авторским намеком на это. Сложность понимания, в свою очередь, скрывается также за непростым процессом декодирования/расшифровки как собственно самого языка, далее же верификации вслед за автором эмоционально-чувственного состояния лирического героя. Следовательно, персонаж поэтического мира формируется как самой естественной природой оценки действительности, так и рецептивной аурой читательских догадок и представлений.

В режиме схожем со Ф. Шлегелем рассуждает о лирике В.Г. Белинский. Для него это то, что занимает, волнует, беспокоит, тревожит и печалит, одновременно с этим услаждает, мучит, успокаивает. Можно дополнить, что лирика - это концентрат, который составляет содержание и суть духовной жизни человека, потенциального читателя. В.Г. Белинский, конечно, был склонен этим тезисом популяризировать литературу, донести до читателя крайности точек зрения. Критик ориентировал на гармоничное восприятие художественного текста, отчасти давал программу оценки, прогнозирования и соединения эстетических горизонтов для раскрытия полноценной картины человеческого бытия. Поэта же неизменно привлекает душевное состояние личности, некая критическая сосредоточенность на внешней и внутреннезаданной реальности, но именно форма в данном случае позволяет совместить чувства и мысли в эстетический метаџентр.

Небезосновательно, что лирическая поэзия еще с античной эпохи была способна запечатлеть/отобразить чувства, вмещенные в условно-зримые пространственно-временные рамки. Внешний формат для лирики есть отправная точка к самому сложному, имманентному, неповторимому. «Все 
многообразные области человеческой деятельности связаны с использованием языка» (Бахтин 1997. 159). Языковые категории - это базис и основа для конкретизации действительного/наличного мира, это почва и арсенал обозначения, очерчивания перспективной магистрали лирических переживаний.

Как отмечал Г.О. Винокур, «язык, употребляемый в поэтических произведениях, может представляться связанным с поэзией не одной только внешней традицией словоупотребления, но и внутренними своими качествами, как язык, действительно соответствующий изображаемому поэтическому миру, выражаемому поэтическому настроению» (Винокур 2006. 26). В поэтическом тексте необычайно широк диапазон языковых контаминаций, манифестация нарочитых лирических концепций, определение стандартно выраженных идейных соображений, конкретизация спектра эмоций. Именно малый формат реализации языковой формы создает концентрацию смысла (Гаспаров 2012), требует для объективности понимания проработки всей языковой, символико-графической системы. Спектр переживаний в лирике многопланов (Безруков 2015. 167). Переживания/чувства могут быть конкретны, условны, открыты, опосредованы, фантастичны, метафоричны, вымышлены. Носителем переживания в лирическом тексте является художественный герой, лирический персонаж отличный от всех ocmaльных. Следует заметить, изначально собственно от потенциального читателя. Он другой не в силу своих сверх уникальных отличий, отличным его делает особый статус, особое положение, особая метафизика эмоций. Дистанция фигуры заглавного персонажа относительно окружающих распространяет этот процессе и на особость мыслей и чувств. Однако художественность, особая типизация лирического героя (уникальность фигуры), качественно обработанный язык текста делает произведение целостно литературным шедевром, который и будет привлекать читателей, остается на протяжении 
долго времени наследием национальной литературы.

В прозе, драме герой выстраивается иначе, в иных нарративных претворениях литературный персонаж становится действенной, реагирующей, декламирующей, манифестирующей фигурой. Теоретические изыскания М.M. Бахтина, Б.О. Кормана, В.Е. Хализева включают мысль о том, что лирический герой более связан с автором, чем в прозе, но, конечно же, не тождествен ему. Он как бы вбирает особое авторское миропонимание, мировосприятие, некий душевный, а главное и духовный опыт. Следует вновь сделать акцент на то, что, эстетически обобщая, поэты достигают той высоты типизации, которая манит читателя, тревожит сознание слушателя.

Взгляд на лирику как систему идеальной взаимозависимости разных уровней стал в методологии литературоведения уже традиционным. И все же лирике присуще особое самораскрытие автора, «распахнутость», «отодвинутость» его внутреннего мира относительно других. Например, анализируя лирику Г.Р. Державина, В.А. Жуковского, А.С. Пушкина, М.Ю. Лермонтова, Ф.И. Тютчева, А.А. Фета, С.Я. Надсона, С.А. Есенина, А.А. Блока, В.В. Маяковского, А.А. Ахматовой, М.И. Цветаевой, А.Т. Твардовского, К. Симонова, Ю. Друниной, С. Гудзенко, А. Вознесенского, Е. Евтушенко, Р. Рождественского, В. Высоцкого, Б. Окуджавы, И. Бродского, Д. Пригова мы получаем яркие представления об их чувствах, намеки на их личную судьбу, ориентиры на трагические моменты, пророческие посыль на знаковые эпизоды. Хотя авторы языково, буквально и не открыты для читателя. Художественный текст, в особенности лирический, всегда остается загадкой, требующей постоянного и постоянного к нему возвращения. Именно поэтому, лирическая поэзия обладает максимально внушающей, заражающей, зовущей силой. Знакомясь с повестью, новеллой, романом или драмой, читатель воспринимает сказанное автором с определенной онтологической дистанции, несколько отстраненно, касаясь только наличной наррации, а далее 
самоопределясь. В лирике нарочито чувства поэта становятся и чувствами переживающего и думающего читателя, этим лирика ближе читательскому, даже, может быть, музыкально-природному естеству. Автор всецело сориентирован на то, чтобы с помощью языка, собственного стиля как особого типа мышления (Безруков 2016. 159- 163) сориентировать читателя со-переживать, со-чувствовать лирическому герою, при этом по возможности максимально погрузиться в его внутренний мир, проникнуться колебаниями его души. Таким образом, лирика несовместима с нейтральностью и беспристрастностью тона повествования, так широко бытующего в эпосе. Основным оператором действенного эффекта в лирике, конечно, является сам язык. Как обозначал М.М. Бахтин, «язык выводится из потребности человека выразить себя, объективировать себя. Сущность языка в той или иной форме, тем или иным путем сводится к духовному творчеству индивидуума» (Бахтин 1997. 168). Поэтический язык, или поэтический дискурс преисполнен особой экспрессией, особой эмоциональностью, которая становится доминантой авторского текста. Экспрессия лирики сказывается в каждом элементе художественного целого: в отборе слов, лексем, в построении синтаксических конструкций, в вариациях иносказания, в особом сложении фраз, главное и начальное, на наш взгляд, - в ритмико-фонетическом, ритмико-мелодическом построении наличного текста.

Сославшись на Ю.М. Лотмана можно принять верифицированный тезис, что «стихотворная речь мыслится как нечто вторичное» (Лотман 1972. 23). Магистралью в лирике являются семантико-фонетические ряды в их неразрывной связи с ритмикой (Гаспаров 2012) и мелодикой (Эйхенбаум 1922). Ритмика есть особый раздел стихосложения (Жирмунский 2004. 258296), который посвящен изучению стихотворной соразмерности языка. «Под ритмом принято понимать правильное чередование, повторяемость одинаковых элементов» (Лотман 1972. 45). Ритм, вероятно, в целом свойствен 
человеческой речи, он также манифестирует и декларирует тон говорящего. В лирическом произведении ритм имеет особое, ничем незаменимое значение, «ритм в стихе является смыслоразличающим элементом» (Лотман 1972. 45).

Исторически сложилось, что основная ритмическая единица начального уровня - это слог. В русском языке слоги воспроизводятся примерно с одинаковой скоростью, вариант плавности обеспечивает понятность и доступность речи для слушателя. Ритмической единицей второго порядка в лирике является стопа. Если взять за основу силлабо-тоническую систему стихосложения, стопа это созвучие одного ударного и одного или двух безударных слогов (ямб/хорей - дактиль/амфибрахий/анапест). Ритмической единицей третьего уровня является стих, или строка. Строка более самостоятельна относительно слога и стопы. Значение строки достаточно велико, ибо это уже есть цельная формула-фраза, наделенная большим потенциально звучащим смыслом. Организуясь в единый массив, стихи образуют текст, который структурно может быть дифференцирован на cmpoфbl. Следовательно, строфа - это группа стихов, объединенных общими формальными признаками. Таким образом, уровневый состав языка организует особую иерархию (Безруков 2017. 45-53) лирики, в которой вариация замены разрушит весь потенциал эстетического и смыслового.

Не менее важен для лирики уровень мелодического строя. Мелодика неотъемлемая часть лирического произведения наряду с ритмикой. Данные уровни как бы дополняют друг друга, создают слитность гармонии языка. Сам термин мелодика происходит от греческого слова напев (Эйхенбаум 1922), что составляет интонационную организацию стиха. Целесообразно, на наш взгляд, предположить, что мелодика есть некое движение голоса в поэтической речи, формально выраженное в повышении и понижении тона, содержательно передающее интонационно-смысловые оттенки целого произведения. Неслучайно, что экспрессивность речи роднит «лирическую напевность» 
(Жирмунский 2004. 318) с музыкальным произведением. Следовательно, мелодика (Тюпа 2008. 118-119; Шатин 2014. 65- 68) связывает наличный состав языка - уровень номинаций - с коннотативной составляющей вариацией синтеза смыслов. Читатель, воспроизводя текст по разным голосовым модусам и моделям, определяет для себя акценты особой значимости, некие точки фиксации имманентного характера. Закономерно, что поэзия не должна говорить языком понятий и определений, наоборот, она стремится воспроизводить в слушателе особое лирическое настроение. Достигается же это звуками, звучащим поэтическим словом (в контраст графическому начертанию), чем его логически-выверенным контентом. На наш взгляд, лирика Константина Бальмонта наиболее яркий тому пример. В поэзии Бальмонта соприсутствует, наличествует то, что упорядочивает через языковой строй авторский смысловой поток.

Функционально творчество К.Д. Бальмонта может быть оценено с позиций разных уровневых доминант. Это тематика текстов, их идейный смысл, сюжетное построение, и собственно поэтическая - ритмико-мелодическая мобильность. Именно ритмико-мелодический строй является существенным, онтологически выверенным для объективной рецепции стиля К. Бальмонта.

Напевный, инструментальный, мелодический характер его стихов во многом зависит от художественных приемов, оборотов и форм, точечной выборки слов с особым интонационно-мелодическим звучанием. В данном случае это влияет и на эмоциональную окраску всего текста, текста как целого (Гальперин 2007), текста как предела авторского способа мышления. Каждое слово у К.Д. Бальмонта имеет свое определенное положение. Трудно заменить уже сформированное единство его лирики в нечто новое, невысказанное. Различные виды смещений, трансформаций разрушают стиль гармоники поэта, изменяют положение авторского, буквально-непрямого взгляда, приводят к дисгармонии сочетаний, нарушают естественную логику 
реализации мысли. Практически любой подобранный автором звуковой элемент (повтор, аллитерация, ассонанс, звукопись), а вместе с ним и лексический конструкт, вводит новое и точно-ограниченное содержание в пределах одной - авторской - эстетической базы. Лирике поэта «серебряного века», символисту, присуща особая острота передачи ощущений, которая видна в его уникальном стиле, манере письма, манере мышления. Обратимся к ряду примеров, подтверждающих акцентность и значимость ритмикомелодической организации лирики Константина Бальмонта.

Гармонично сформировать картинку естественного бытия для поэта не представляется сложным. Но автор гармонию языковых номинаций, буквальных ориентиров дополняет мелодикой и ритмикой русского языка. Это проявляется уже в его раннем творчестве, например, в стихотворении «Фантазия» (1893):

\footnotetext{
Как живые изваянья, в искрах лунного сиянья,

Чуть трепещут очерт $a$ нья сосен, елей, и берез;

Вещий лес спокойно дремлет, яркий блеск Луны приемлет,

И роптанью ветра внемлет, весь исполнен тайных грез (Т. 1, с. 24).
}

Представленный в тексте звуковой состав нарочито обыгрывается поэтической инструментовкой, выраженной звукописью ассонанса и аллитерации. Также в формате звукописи, особой мелодики выступают у К.Д. Бальмонта и nаронимы. По характеру они чаще всего представлены сопоставительными парами: топот / ропот; я ждал / я жаждал; слова / славы; мирной / мерной; чаю / чую и т.д. Далее утверждаемся в этом предположении на примере стихотворения «Грусть» (1894):

Внемля ветру, тополь гнется, с неба дождь осенний льется,

Надо мною раздается мерный стук часов стенных; 
Мне никто не улыбнется, и тревожно сердце бьется,

И из уст невольно рвется монотонный грустный стих;

И как тихий дальний топот, за окном я слышу ропот,

Непонятный странный шопот - шопот капель дождевых (Т. 1, с. $53)$.

Следует заметить, что для Константина Бальмонта звуковой, да и синтаксический повтор есть форма создания текста. Способ активного сращения языковых рядов в единый монолит фразы. Буквально, вариация стыка - есть основа стихотворения «Я мечтою ловил уходящие тени...» (1894). Данное стихотворение ступенчато, сюжетно ведет читателя/реципиента от низа мировой арены с некой «тенью небытия»к вершине жизни, естеству желаемого, от намеченной, иллюзорной тени к цели бытия.

Я мечтою ловил уходящие тени,

Уходящие тени погасавшего дня,

Я на башню всходил, и дрожали ступени,

И дрожали ступени под ногой у меня.

И чем выше я шел, тем ясней рисовались,

Тем ясней рисовались очертанья вдали,

И какие-то звуки вдали раздавались,

Вкруг меня раздавались от Небес и Земли (Т.1, с. 56).

Звуково шаги лирического героя, авторского $Я$, мелодически подчеркивает

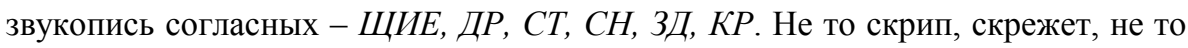
преодоление, переступание через что-либо, но образ движется к желаемому, своей вершине. Риторически, достигается ли она - решать реципиенту. Не 
случайно стихотворение заканчивается анафорической формой повтора, связывающего начало и конец текста:

Я узнал, как ловит уходящие тени,

Уходящие тени потускневшего дня,

И все выше я шел, и дрожали ступени,

И дрожали ступени под ногой у меня (Т.1, с. 56).

Читателю обыграть Константина Бальмонта в вариантном сложении звуков, особой инструментовке, а далее и в режиме смысловой констатации нелегко. Его языковая картина мира индивидуального рода, статусного порядка. Мышление автора не вторит языку, оно движется чуть быстрее, но заметнее. В языковом сложении нет той нарочитой пустоты, которую можно заполнить только звуками, фонетикой сказанного. Мир для К.Д. Бальмонта есть свет солнца, свет души, метафизика ирреальности смешанной со «страшной картинкой» бытия, неслучайна созвучность его языка/манеры с эстеткой и поэтикой символизма. В частности, стихотворение «Камыши» (1895) репрезентирует:

Полночной порою в болотной глуши

Чуть слышно, бесшумно, шуршат камыши.

О чем они шепчут? О чем говорят?

Зачем огоньки между ними горят?

Мелькают, мигают, - и снова их нет.

И снова забрезжил блуждающий свет.

Полночной порой камыши шелестят.

В них жабы гнездятся, в них змеи свистят (Т.1, с. 59). 
Читатель на первый взгляд качественно воссоздает перед собой пейзажный фон, на котором и разворачиваются основные события вечерней «жизни» полночь, болотная глушь, камыши, блуждающий свет, мелест камылшей, жабы, змеи. У Бальмонта просто не может такого быть. Именно ритмика текста, звуковая авторская аранжировка создают эффект дыхания жизни ШИ, ШИ, РЯТ, РЯТ, HET, HET. Помогает в данном случае и формат дистиховой строфики; парность - это вдох, выдох, вздох, выдох... Конечно же, финал текста особо значим для верификации стилевой манеры Константина Бальмонта:

И, вздох повторяя погибшей души,

Тоскливо, бесшумно, шуршат камыши (Т.1, с. 59).

Завершает естественное дыхание жизни финальная строка, она же и останавливает жизнь. Таким образом, нарушен читательский комфорт, снято ограничение на переживание и автор смог вовлечь читателя в интенсивный акт со-творчества, со-переживания. Сделано это в первую очередь, ритмикомелодической организацией, далее уже - словом и слитностью синтаксиса.

В лирике поэта не раз встречается введение в текст внешней стихии. Как уже отмечалось ранее, трансцендентальное для поэта есть только повод сказать что-то большее, проникнуть с помощью нарочитой, гремящей, пугающей картины в потаенность внутреннего мира. Но и буквальное звучание стихии, что немаловажно для Константина Бальмонта, отражено в стихотворении «Океан» (1895):

Вдали от берегов Страны Обетованной,

Храня на дне души надежды бледный свет.

Я волны вопрошал, и Океан туманный

Угрюмо рокотал и говорил в ответ (Т.1, с. 64). 
Стихотворение с самого начала наполнено двойственностью стандартов. Внешняя картина - «волны», «свет» - ориентирует на внутренне-желаемую «обетованная страна», «туманный океан». В данном случае движение потоков страсти-желания редуцировано мелодикой текста, приемом, воспроизводящим интенсивный процесс говорения - РО-КО-ТАЛ, ГО-ВО-РИЛ. Лирический герой/автор «вопрошает» у природы, стихии бурной, неспокойной; но и герой ждет ответа на вопрос, но получает в ответ следующее:

«Забудь о светлых снах. Забудь. Надежды нет.

Ты вверился мечте обманчивой и странной.

Скитайся дни, года, десятки, сотни лет, -

Ты не найдешь нигде Страны Обетованной» (Т.1, с. 64-65).

Символично, что Константин Бальмонт использует в данном фрагменте молитвенную формулу, некую модель ретардации, которая строится по особым принципам ритмики и мелодики - повтор, монотон, акцент, возврат, трансвариант, гипнотический эффект слова. Внутренний повтор, повтор непрямой, сокрытый дает возможность автору, а далее и потенциальному читателю преодолеть смысловой контрапункт не лексически, но фонетически, с помощью звукописи - «Забудь... Забудь... Скитайся...». Заклинание словом работает как проекция мыслительного уровня, что свидетельствует о тщательной обработке не только языкового элемента, но и мысли, концептов, ментальных схем миропонимания.

На наш взгляд, в лирике Константина Бальмонта читателя покоряет не столько идея самого наличного текста (идеальная формула), сколько чарующая динамика и пластика, гармоничность стиха, его музыкальность, создаваемая волнообразным движением интонационных подъемов и спадов, даже внутренних колебаний голоса. Как бы выхватив звук - реципиент переживает контекстуальное состояние бессознательно, интуитивно предвидя 
извод, это делает лирику поэта продуктом совершенным и качественным. Исходя из сказанного, можно отметить, что отличие поэзии К.Д. Бальмонта от ряда близких ему поэтов XX века в ориентире на начало рождения мысли звук. Следовательно, в его текстах встречаем и оцениваем как генетический признак, рецептивный код и паронимию, и ассонанс, и аллитераццию, и звукопись, и мелодику, и особую ритмику, и парономазию, и парцелляцию, и умолчание. Функциональна для Константина Бальмонта вся звуковая база современного русского языка, языка особо мелодичного, напевного, яркого.

Мелодика его текстов есть своеобразный аттрактант; собственно притяжение достигается за счет «внутренней формы» (А.А. Потебня), за счет динамичной свободы в колористически-звуковой организации. Конкретизировать же роль того или иного приема, формы, средства необходимо из контекста, близкой связности звуков, лексем, синтаксических номинаций. Так, например, если обратиться к стихотворению «Вечнобезмолвное небо...» (1895) видим модульную связность звуков [В-Б], [М-Н] и смысловых коннотаций [ВЕЧНОСТЬ - ПРЕКРАСНОЕ], [НЕБО - МOРЕ]:

Вечно-безмолвное Небо, смутно-прекрасное Море,

Оба окутаны светом мертвенно-бледной Луны.

Ветер в пространстве смутился, смолк в безутешном просторе,

Небо, и Ветер, и Море грустью одною больны (Т.1, с. 65).

На наш взгляд, именно ритмика и мелодика К.Д. Бальмонта особый вопрос, который уже не раз поднимался в научной среде, но окончательно систематизировать имеющиеся данные не получается, так как в его наследии мелодику задает ритм, а ритмика неразрывно связана с интонированием. Этим он и интересен, этим же интересен ситуативно-используемый автором язык. Например, в стихотворении «Опять» (1899): 


\begin{abstract}
Я хотел бы тебя заласкать вдохновением,
Чтоб мои над тобой трепетали мечты,

Как струится ручей мелодическим пением

Заласкать наклонившихся лилий цветы,

Чтобы с каждым нахлынувшим новым мгновением
\end{abstract}

$T b l$ шептала: «Опять! Это - mbl! Это - mы !» (Т.1, с. 222).

Рецепция этого текста для читателя внешне понятна, она как бы находится на поверхности, однако, стилистические магистрали авторского языка маркируются, читателю дается лишь только намек на что-то эмоциональночувственное. Текст, как видим, произносится на одной голосовой волне, как бы пропевается, смыслы же стихотворения остаются тайной до конца. Они близки романтике чувств, нежности переживаний, сложности страстей, непредвиденности взаимоотношений, дистанции контакта, трепетности эмоций, доставляющей радость и удовольствие. И это нравиться не только лирическому герою, автору, но и читателю. Последний как бы заражается желанием «заласкать вдохновением», но потенциал рядового масштаба вряд ли способен это сделать именно так, так как это смог К.Д. Бальмонт.

В рамках органики стихосложения языка нельзя не оценить поистине выверенный анапест Бальмонта, хотя бы в стихотворении «Меж подводных стеблей» (1903):

Хорошо меж подводных стеблей.

Бледный свет. Тишина. Глубина.

Мы заметим лишь тень кораблей,

И до нас не доходит волна.

Неподвижные стебли глядят,

Тонкоствольные стебли растут. 
Как спокоен зеленый их взгляд,

Как они бестревожно цветут (Т.2, с. 81).

В данном случае, ритмический рисунок балансирует на грани эффекта мерцания и представления, колебаний реальности живой природы. Неспешность хода жизни - целостная авторская установка. Верх/низ, лево/право в традиционном особом пространственном режиме для данного текста незначимы; чуткость, тишина, тень, взгляд, ияветение - вот, что онтологически тревожит сознание автора/читателя. Вновь Бальмонт ориентирует реципиента на условность, дает лишь намек на событие, может быть, даже особого состояния. И в тоже время автор беспристрастен к изменениям не только внешнего, но и внутреннего характера, ямбическая стопа в помощь поэту. Стихотворение «Я тихо сплю на дне морском...» (1913):

Я тихо сплю на дне морском,

Но близок мир земли.

Я вижу, верховым путем

Проходят корабли.

И видя бледность глубины

И жемчуга ее,

Я вспоминаю зыбь волны,

Тревожу забытье (Т.2, с. 82).

Константину Бальмонту не было свойственно смешение разных стоп в плане ритмики, но и говорит о цельности, неразделенности поэтической мысли, особом концептуальном сложении фразы, а также статусной роли «воспроизводящего», ответственности за произнесенное им, им написанное. 
Стоит указать также на то, что стиль для лирики, в особенности для поэзии К.Д. Бальмонта, есть особая форма выражения или особый тип мышления. Глубинный дух фразы, ее понимание достигается только в ходе медленного чтения, «чтения вслед за автором». Сочетая, буквально вторя самому себе, автор не дистанцируется относительно текста, он растворяется в нем, приращивает себя к творческой вариации движения. Разгадать природу поэзии Константина Бальмонта можно только одномоментным принятием для себя и ритма, и мелодики, и лексики, и синтаксиса. Читатель, безусловно, должен не забывать, что перед ним эстетическое целое, дифференциация, дробность которого на части приводит к разрушению авторского стандарта, дроблению стилевого применение языка на практике.

\section{Заключение}

Таким образом, рецепция и анализ индивидуально-стилевой манеры лирики К.Д. Бальмонта, позволяет сделать вывод о высокой значимости ритмики и мелодики в его лирическом наследии. Поэтические тексты Бальмонта передают чувства, эмоции, переживания, для которых недостаточна, а порой и второстепенна, содержательная, собственно смысловая сторона. Наибольшую важность играет в тексте не само слово, лексема, а их подача и звучание, выгодное и принципиально авторское построение, далее же - сложное, многомерное, многогранное читательская оценка и понимание.

Гармоническая цельность лирики К.Д. Бальмонта основная примета его стиля, способа мышления. Автор от читателя требует особого внимания на специфику языкового использования, особой дешифровки семантики звуковых соответствий, фонетических контаминаций. Сам автор конкретизировал, что за основу оценки нужно бать «мерную лиричность взнесенного чувства и умудренного сознания». На наш взгляд, это и есть первооснова колебаний, 
первооснова движений чувственной базы, которая регулируется стилем как особой формы мыслить. Познать и качественно проанализировать язык Константина Бальмонта, объективировать его для современности можно только при детальной оценке мелодики и ритмики, фоники и звукописи.

Также немаловажно, что лирика Константина Бальмонта продуктивна, функциональна и действенна. Она особо значима для диалога культурных этапов, ибо собирает фольклор прошлого, историзм настоящего, перспективность вечного. Литературный процесс XX века достаточно частотно обращается к наследию Бальмонта за формой поддержки, за гармонией созвучности, за прилежностью стиха. Все это происходит благодаря созвучности и складности русского языка, смежности культурных парадигм, стилевой слитности национальных приоритетов. Стиль Константина Бальмонта противоречив, неоднозначен, окончательно утвердиться в правильности понимания его языка несколько бессмысленно. Сферический вариант коннотаций у Бальмонта онтологически превалирует, метафизически поэт расширяет объем звучащего слова, за счет этого обогащается и внутренний мир читателя. Прикасаясь к наследию К.Д. Бальмонта необходимо учитывать, не только объем его поэтического богатства, не стоит забывать и про эстетику начальных языковых номинаций, реализованных в индивидуально-авторской манере.

\section{Литература}

1- Бальмонт К.Д. (2010а). Собр. соч.: В 7-ми m. Т.1.: Полное собрание стихов 1909 - 1914: Кн. 1-3 / К.Д. Бальмонт / Вступ. ст. В. Макарова. Москва: Изд-во «Книжный Клуб Книговек».

2- Бальмонт К.Д. (2010б). Собр. соч.: В 7-ми т. Т.2.: Полное собрание стихов 1909 - 1914: Кн. 4-7 / К.Д. Бальмонт. Москва: Изд-во «Книжный Клуб Книговек».

3- Бахтин М.М. (1997). Собр. соч.: в 7-ми т. Т.5. Работы 1940-х-начала 1960-х годов / М.М. Бахтин. Москва: Изд-во «Русские словари». 
4- Безруков А.Н. (2015). Рецепциия художественного текста: функциональный подход / А.Н. Безруков. Вроцлав: Изд-во: Фонд «Русско-польский институт».

5- Безруков А.Н. (2016). Диссолюичи стиля $u$ дискурса в пределах онтологического корпуса художественных нарращий / А.Н. Безруков // Актуальные проблемы стилистики. № 2. С. 159-163.

6- Безруков А.Н. (2017). Иерархия художественного дискурса / А.Н. Безруков // Litera. № 2. C. 45-53.

7- Винокур Г.О. (2006). О языке художественной литературы / Г.О. Винокур. Москва: Изд-во «КомКнига».

8- Гальперин И.Р. (2007). Текст как объект лингвистического исследования / И.Р. Гальперин. Москва: Изд-во «КомКнига».

9- Гаспаров М.Л. (2012). Метр и смысл / М.Л. Гаспаров. Москва: Изд-во «Фортуна ЭЛ».

10- Жирмунский В.М. (2004). Введение в литературоведение: Курс лекций / В.М. Жирмунский. Москва: Изд-во «Едиториал УРСС».

11- Лотман Ю.М. (1972). Анализ поэтического текста / Ю.М. Лотман. Ленинград: Изд-во «Просвещение».

12- Молчанова Н.А. (2002). Поэзия К. Бальмонта 1890-х - 1910-х годов: проблемы творческой эволюичи / Н.А. Молчанова. Москва: Изд-во «МПГУ».

13- Петрова Н.Г. (2015). Лексические регуляторы в аспекте читательского восприятия (на материале поэзии К. Бальмонта) / Н.Г. Петрова. Новосибирск: Изд-во «НГПУ».

14- Петрова Т.В. (2012). Поэт солнца и волшебных звуков (К. Бальмонт и С. Прокофьев) / Т.В. Петрова. Иваново: Изд-во «Епишева О.В. ».

15- Суханова И.А. (2016). Роль имен художников в стихотворении «Аккорды» $K$. Бальмонта с точки зрения интермедиальных связей / И.А. Суханова // Ярославский текст в пространстве диалога культур. Материалы науч. конф. Ярославль: Изд-во «Ярослав. гос. пед. ун-т им. К.Д. Ушинского». С. 303-308.

16- Тюпа В.И. (2008). Анализ художественного текста: учеб. пособие / В.И. Тюпа. Москва: Издательский центр «Академия».

17- Хализев В.Е. (2004). Теория литературы / В.Е. Хализев. М.: Изд-во «Высшая школа».

18- Шатин Ю.В. (2014). Б.М. Эйхенбаум и В.М. Жирмунский: две интерпретации мелодики стиха / Ю.В. Шатин // Известия Воронежского государственного университета. № 4(265). С. 65- 68 . 
19- Шлегель Ф. (1983). Эстетика. Философия. Критика. В 2-х т. Т.2 / Ф. Шлегель. Москва: Изд-во «Искусство».

20- Эйхенбаум Б.М. (1922). Мелодика русского лирического стиха / Б.М. Эйхенбаум. Петербург: Изд-во «ОПОЯЗ».

\section{Bibliography}

1- Bal'mont K.D. (2010a). Sobr. soch.: V 7-mi t. T.1.: Polnoe sobranie stihov 1909 1914: Kn. 1-3 / K.D. Bal'mont / Vstup. st. V. Makarova. Moskva: Izd-vo «Knizhnyj Klub Knigovek».

2- Bal'mont K.D. (2010b). Sobr. soch.: V 7-mi t. T.2.: Polnoe sobranie stihov 1909 1914: Kn. 4-7 / K.D. Bal'mont. Moskva: Izd-vo «Knizhnyj Klub Knigovek».

3- Bahtin M.M. (1997). Sobr. soch.: v 7-mi t. T.5. Raboty 1940-h - nachala 1960-h godov / M.M. Bahtin. Moskva: Izd-vo «Russkie slovari».

4- Bezrukov A.N. (2015). Recepcija hudozhestvennogo teksta: funkcional'nyj podhod / A.N. Bezrukov. Vroclav: Izd-vo: Fond «Russko-pol'skij institut».

5- Bezrukov A.N. (2016). Dissoljucija stilja i diskursa v predelah ontologicheskogo korpusa hudozhestvennyh narracij / A.N. Bezrukov // Aktual'nye problemy stilistiki. № 2. S. 159-163.

6- Bezrukov A.N. (2017). Ierarhija hudozhestvennogo diskursa / A.N. Bezrukov // Litera. № 2. S. 45-53.

7- Vinokur G.O. (2006). O jazyke hudozhestvennoj literatury / G.O. Vinokur. Moskva: Izd-vo «KomKniga».

8- Gal'perin I.R. (2007). Tekst kak ob\#ekt lingvisticheskogo issledovanija / I.R. Gal'perin. Moskva: Izd-vo «KomKniga».

9- Gasparov M.L. (2012). Metr i smysl / M.L. Gasparov. Moskva: Izd-vo «Fortuna JeL».

10- Zhirmunskij V.M. (2004). Vvedenie v literaturovedenie: Kurs lekcij / V.M. Zhirmunskij. Moskva: Izd-vo «Editorial URSS».

11- Lotman Ju.M. (1972). Analiz pojeticheskogo teksta / Ju.M. Lotman. Leningrad: Izdvo «Prosveshhenie».

12- Molchanova N.A. (2002). Pojezija K. Bal'monta 1890-h-1910-h godov: problemy tvorcheskoj jevoljucii / N.A. Molchanova. Moskva: Izd-vo «MPGU».

13- Petrova N.G. (2015). Leksicheskie reguljatory v aspekte chitatel'skogo vosprijatija (na materiale pojezii K. Bal'monta) / N.G. Petrova. Novosibirsk: Izd-vo «NGPU». 
14- Petrova T.V. (2012). Pojet solnca i volshebnyh zvukov (K. Bal'mont i S. Prokof'ev) / T.V. Petrova. Ivanovo: Izd-vo «Episheva O.V. ».

15- Suhanova I.A. (2016). Rol' imen hudozhnikov v stihotvorenii "Akkordy» K. Bal'monta s tochki zrenija intermedial'nyh svjazej / I.A. Suhanova // Jaroslavskij tekst $v$ prostranstve dialoga kul'tur. Materialy nauch. konf. Jaroslavl': Izd-vo «Jaroslav. gos. ped. un-t im. K.D. Ushinskogo». S. 303-308.

16- Tjupa V.I. (2008). Analiz hudozhestvennogo teksta: ucheb. posobie / V.I. Tjupa. Moskva: Izdatel'skij centr «Akademija».

17- Halizev V.E. (2004). Teorija literatury / V.E. Halizev. M.: Izd-vo «Vysshaja shkola».

18- Shatin Ju.V. (2014). B.M. Jejhenbaum i V.M. Zhirmunskij: dve interpretacii melodiki stiha / Ju.V. Shatin // Izvestija Voronezhskogo gosudarstvennogo universiteta. № 4(265). S. 65- 68.

19- Shlegel' F. (1983). Jestetika. Filosofija. Kritika. V 2-h t. T.2 / F. Shlegel'. Moskva: Izd-vo «Iskusstvo».

20- Jejhenbaum B.M. (1922). Melodika russkogo liricheskogo stiha / B.M. Jejhenbaum. Peterburg: Izd-vo «OPOJaZ».

\section{HOW TO CITE THIS ARTICLE}

Bezrukov Andrey Nikolaevich (2018). Reception of Individual Stylistic Manners the Lyrics of K.D. Balmont, Issledovatel'skiy Zhurnal Russkogo Yazyka i Literatury, 11(1): pp:115-137

DOI: 10.29252 /iarll.11.115

URL: http://journaliarll.ir/article-1-131-en.html

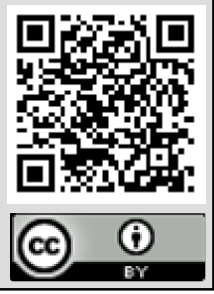




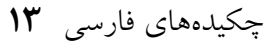

\title{
تفسير و تأويل ويزگىهاى سبكى و ادبى مؤلف در آثار غنايى ك.د. بالمونت
}

\author{
آندرى نيكالايويج بيزروكوف'

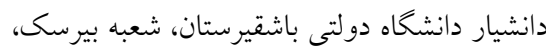

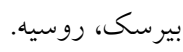

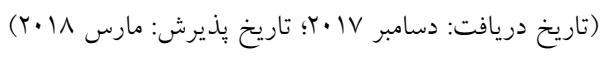

شناسايى ويزَكى هاى سبكى و ادبى مؤلف در تحليل زبانشناختى متون ادبسى امـرى بـسيار

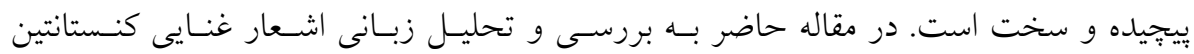

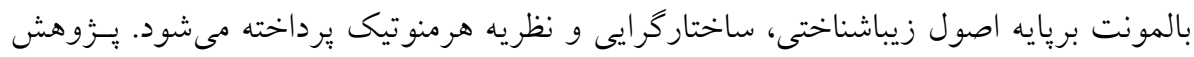

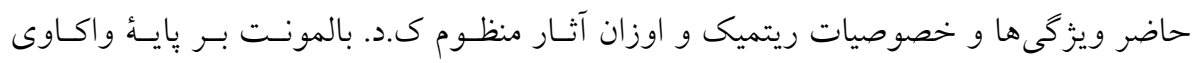

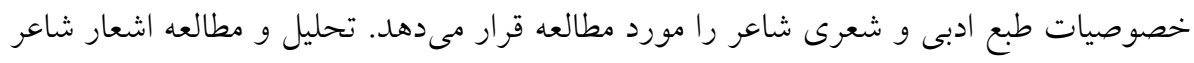

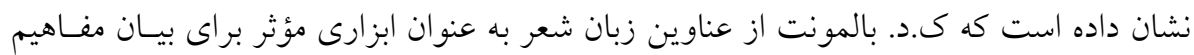

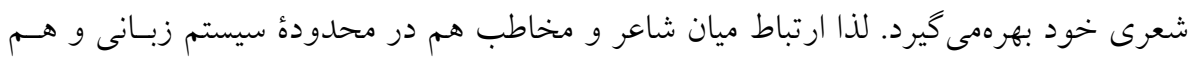

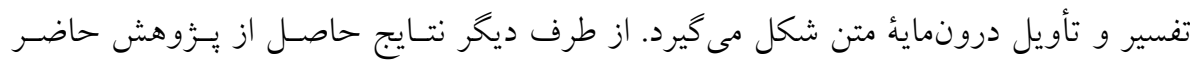

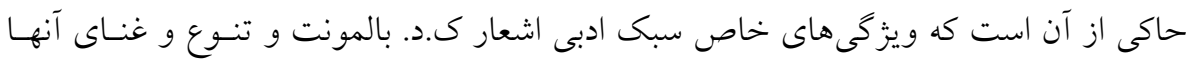

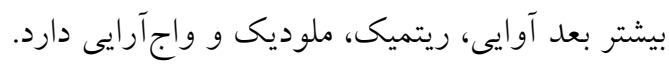

وازگًان كليدى: كنستانتين بالمونت، تفسير و تأويل متن، سبك شعر، زبان شعر، ملودى، ريـتم، بار معنايى متن، كفتمان ادبى. وكن. 